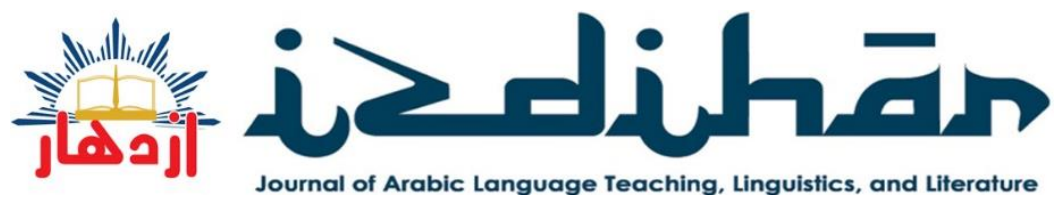




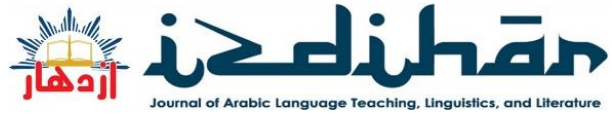

Vol. 1 No. 2, Desember 2018

p-ISSN : 2622-738X

e-ISSN : 2622-7371

\section{Tim Redaksi:}

\section{Editor in Chief:}

Moh. Fery Fauzi

Managing Editor:

Ahmad Fatoni

Anisatu Thoyyibah

Editor:

Abdul Haris

M. Firdaus

Lailatul Mauludiyah

\section{Cover Designer:}

Dodi Prastiyo

\section{Mitra Bestari (Reviewer):}

Md. Qutbuddin

(Jawaharlal Nehru India)

Gareeb Allah Babiker Musthofa

(Omdurman Islamic University, Sudan)

Talqis Nurdianto

(Universitas Muhammadiyah Yogyakarta)

Hisyam Zaini

(UIN Sunan Kalijaga Yogyakarta)

Abdul Haris 
(Universitas Muhammadiyah Malang)

Ahmad Fatoni

(Universitas Muhammadiyah Malang) 